\title{
President of the Methodist Conference v Preston
}

Court of Appeal: Maurice Kay and Longmore LJJ and Sir David Keene, December 2011

Clergy - employment status

The court held that, as a result of the judgment in Percy $v$ Board of National Mission of the Church of Scotland [2006] 2 AC 28, the rebuttable presumption that, viewed objectively, there was an absence of any intention to create an employer-employee relationship between an individual cleric and the church within which he or she ministered had been abandoned. The earlier ruling in President of the Methodist Conference v Parfitt [1984] ICR 176, that the nature of the relationship between the individual minister and the Methodist Church was a spiritual one and that ministers were not, therefore, employed under a contract of service, was no longer binding. It was for employment tribunals to decide on the facts whether or not the statutory criteria of unfairness had been met in any individual case. A finding of an employer-employee relationship would not violate the church's right to manifest its religion under Article 9 of the ECHR. [Frank Cranmer]

\section{All Saints, Monkwearmouth}

Durham Consistory Court: Bursell Ch, December 2011 Aumbry

The chancellor refused to grant a faculty for the introduction of an aumbry on the basis that to do so would be to facilitate an illegal rite. The aumbry was intended to be used to store the consecrated elements from the preceding Sunday service for use in what was termed 'Communion by Extension' at Wednesday morning services. The chancellor referred to Canon B2 and the House of Bishops' Guidelines on Public Worship with Communion by Extension (October 2000). He concluded that the arrangements in place could not amount to Communion by Extension, given the greater than minimal interval between the services. He further held that the proposed arrangements could not amount to a variation 'not of substantial importance' under Canon B 5 and thus the proposed rite was illegal. [RA] 